Review

\title{
Supply Chain Risk Management: Literature Review
}

\author{
Amulya Gurtu 1,*(D) and Jestin Johny ${ }^{2}$ (D) \\ 1 Austin E. Cofrin School of Business, University of Wisconsin-Green Bay, Green Bay, WI 54311, USA \\ 2 Department of Humanities and Social Science, BITS Pilani, K. K. Birla Goa Campus, Goa 403726, India; \\ p20180038@goa.bits-pilani.ac.in \\ * Correspondence: gurtua@uwgb.edu; Tel.: +1-920-465-2509
}

\section{check for}

updates

Citation: Gurtu, Amulya, and Jestin Johny. 2021. Supply Chain Risk Management: Literature Review. Risks 9: 16. https://doi.org/10.3390/ risks9010016

Received: 17 November 2020

Accepted: 1 January 2021

Published: 6 January 2021

Publisher's Note: MDPI stays neutral with regard to jurisdictional clai$\mathrm{ms}$ in published maps and institutional affiliations.

Copyright: (C) 2021 by the authors. Licensee MDPI, Basel, Switzerland. This article is an open access article distributed under the terms and conditions of the Creative Commons Attribution (CC BY) license (https:// creativecommons.org/licenses/by/ $4.0 /)$.

\begin{abstract}
The risks associated with global supply chain management has created a discourse among practitioners and academics. This is evident by the business uncertainties growing in supply chain management, which pose threats to the entire network flow and economy. This paper aims to review the existing literature on risk factors in supply chain management in an uncertain and competitive business environment. Papers that contained the word "risk" in their titles, keywords, or abstracts were selected for conducting the theoretical analyses. Supply chain risk management is an integral function of the supply network. It faces unpredictable challenges due to nations' economic policies and globalization, which have raised uncertainty and challenges for supply chain organizations. These significantly affect the financial performance of the organizations and the economy of a nation. Debate on supply chain risk management may promote competitiveness in business. Risk mitigation strategies will reduce the impact caused due to natural and human-made disasters.
\end{abstract}

Keywords: risk management; outsourcing risk; supply risk; risk sharing; process management; supply chain disruptions

\section{Introduction}

International trade leads to global supply chains, and risks are inherent in supply chain management (SCM). Globalization and trade openness have amplified the vulnerability in SCM and increased the risks. The monetary value of supply chain expenses is the highest in manufacturing organizations (Dey et al. 2011). Nonetheless, SCM risks are assumed to be non-financial risks in the traditional sense of risk in the finance and insurance industries.

Risk management refers to the implementation of strategies and plans to manage supply chain networks through constant risk assessment and reduce vulnerabilities to ensure resilience in supply chains. All supply chains do not have the same risks, but some risks are common. The risks are also specific to an area of business or the field of study (Jemison 1987). A supply chain is as strong as the most vulnerable member of the supply chain. Therefore, the longer a supply chain, the greater the risk of failure of the supply chain. Supply chains have many players. A high number of players present risks (Braithwaite and Hall 1999). However, building a robust supply chain is expensive (Vahid Nooraie and Parast 2016). Numerous research articles have suggested the need for such supply chains due to the magnitude of the adverse effects of risk on its performance (Chandra and Grabis 2007; Chopra and Sodhi 2014; Christopher and Lee 2004; Ritchie and Brindley 2007).

Supply chain risk management (SCRM) is a systematic and phased approach for recognizing, evaluating, ranking, mitigating, and monitoring potential disruptions in supply chains (Aqlan and Lam 2016). SCRM is an important area due to an incident's cascading effects on logistics networks (Cigolini and Rossi 2010). Some examples of such events include September 11, the Gulf War, the outbreak of a pandemic (e.g., bovine spongiform encephalopathy, and coronavirus disease 2019, COVID-19), the millennium bug. These disruptive events have compelled practitioners to explore the vulnerabilities in 
supply chains and evaluate risks. Vulnerabilities in a supply chain depend on the supply chain (Caniato and Rice 2003; Chapman et al. 2002). Moreover, the COVID-19 pandemic has resulted in disruption to the mechanics of most economies, irrespective of their size and phase of development.

Globalization, shorter product lifecycles, multifaceted networks of trade partners located in many countries, uncertainty in market demands, cost pressures, outsourcing, and offshoring are a few risks in SCM (Hachicha and Elmsalmi 2014; Lavastre et al. 2012). The complexities of SCM are rising, and the networks are becoming more complex, resulting in more uncertainty in the business environment (MeInyk et al. 2005; Sofyalıoglu and Kartal 2012; Thun et al. 2011; Verbano and Venturini 2011). These represent risk events in supply chains that impact the entire supply chain network (Cagliano et al. 2012; Fernandes et al. 2011; Xanthopoulos et al. 2012). A risk event is an indicator of a threat that disrupts a supply chain (Fernandes et al. 2011; Huang et al. 2009). Global supply chains have many challenges and greater risks (Blackhurst et al. 2005; Chopra and Sodhi 2004; Tang 2007). The dependence on an organization for parts has changed to a supply chain (Christopher 1992). This requires greater transparency and sharing of information among supply chain players.

Global production practices have changed due to globalization and nations' economic engagements with partner countries. These have increased complexities and various forms of risks in supply chains. Organizations have created warehouse facilities, production plants, and fulfillment centers across countries to achieve cost benefits, access to cheaper raw material sources, or specialist skills and capabilities (Choi et al. 2012). The distribution centers in the modern era of global supply chains are also known as fulfillment centers. A fulfillment center is where customer demands are fulfilled. Therefore, these centers must be efficient because these centers' efficiency affects the entire SCM value.

Significant emphasis is to be employed on the impact of disasters distressing the supply chain and ensuring effects on operational performance (Prasad et al. 2016; Wang et al. 2014). Craighead et al. (2007) suggested that, "supply chain interruptions and the associated operational and financial risks represent the most pressing concern facing firms that compete in today's worldwide marketplace." Risk in a supply chain is "the likelihood of an adverse and unexpected event that can occur, and either directly or indirectly result in a supply chain disruption" (Garvey et al. 2015). However, there is a difference between disruption and risk. Disruption is an indicator of risk in supply chains. Nonetheless, risks exist without disruption. The 2011 tsunami in Japan affected the auto industry globally for months. Furthermore, floods in Thailand later in the same year affected the supply chains of semiconductors and auto manufacturing plants in Thailand (Chopra and Sodhi 2014).

Risks cause disruption, which ripples through the network of the supply chains. SCRM ensures the smooth functioning of supply chains (Christopher and Lee 2004). Risk can be termed as vulnerability, uncertainty, disruption, disaster, peril, or hazard. A lack of foresight about a likely disruption in a supply chain and its causes makes a supply chain vulnerable, and the SCM leaders less effective (Vorst et al. 1998). Uncertainty and risk have been used interchangeably in SCM. Uncertainty has more than one possibility and, therefore, is difficult to calculate (Knight 1921). Risk comes from uncertainty, which has a few possibilities (Hubbard 2007, 2020). However, risks can be quantified. SCRM is a strategic view of supply chains in an organization, and SCRM includes supply chain security (Williams et al. 2008).

This paper reviewed articles published from 2010 until the end of December 2019 to assess the word "risk" used in different areas/sectors under study. The analysis considered the frequency of risk as a keyword used in journals that published such articles in various research disciplines. The remainder of the paper is organized as follows: the second section presents a review of the relevant literature on SCRM and discusses the research methodology. The third section provides analyses, and Section 4 presents research implications for SCRM professionals. Section 5 concludes the research discussion on the risk and its impact on the supply chain network. 


\section{Literature Review and Research Design}

The supply chain network consists of trade-offs interrelated by monetary, information, and material flows (Fugate et al. 2006). Many disruptions in supply chains have been seen since the year 2000. These disruptions include the fear of weapons of mass destruction, terrorist attacks, fuel protests, and disease outbreaks (Jüttner 2005). The risk is the probability of differences in expected outcomes (Spekman and Davis 2004). One can assign probabilities to various outcomes and calculate risk (Khan and Burnes 2007). However, uncertainty cannot be quantified (Knight 1921). Risk means that there is uncertainty about an outcome (Teigen 1996). Hence, uncertainty refers to a risk that may not be eliminated. However, these uncertainties can be minimized with proper assessment and planning (Slack and Lewis 2002).

SCRM can be divided into two broad categories of approaches. The first is the strategy for comprehensive risk management approach (Azad et al. 2012; Christopher and Peck 2004; Craighead et al. 2007; de Matta 2016; Tang 2007; Xu et al. 2015), and the second is a focused approach to a specific disruption. These specific disruptions could be security (Véronneau and Roy 2014), lead times (Kouvelis and Li 2008), or terrorism (Sheffi 2001). Although these methods provided enormous value and insights, the events causing disruption were presumed to be unintentional. The lack of risk managing strategies to understand the cause of disruption leaves a gap from a theoretical perspective, exposing firms to unavoidable risks in the environment. Children's toys contained lead-based paint in 2007 without the knowledge of Mattel. This caused disruptions in Mattel's supply chains. Mattel ended up setting quality assurance centers at the suppliers' factories to avoid the repetition of the lead paint crisis. The supplier used lead-based paint to save small operational costs. The cost of disruption to Mattel was much more significant and could have been avoided (Roloff and Aßländer 2010).

The remainder of the section is divided into four subsections. The first subsection reviews the past literature for various definitions of risk. The second subsection discusses risk disruption in SCM caused by natural disasters or events which are beyond human control. Risk disruption can occur due to weak supply chain strategies. The third subsection discusses risk management methods and strategies. The fourth subsection illustrates risk detection and risk mitigation in the supply chain network for a contingency plan and supplier evaluation to be carried for reducing risk impact and achieving supply chain resilience (Figure 1). 


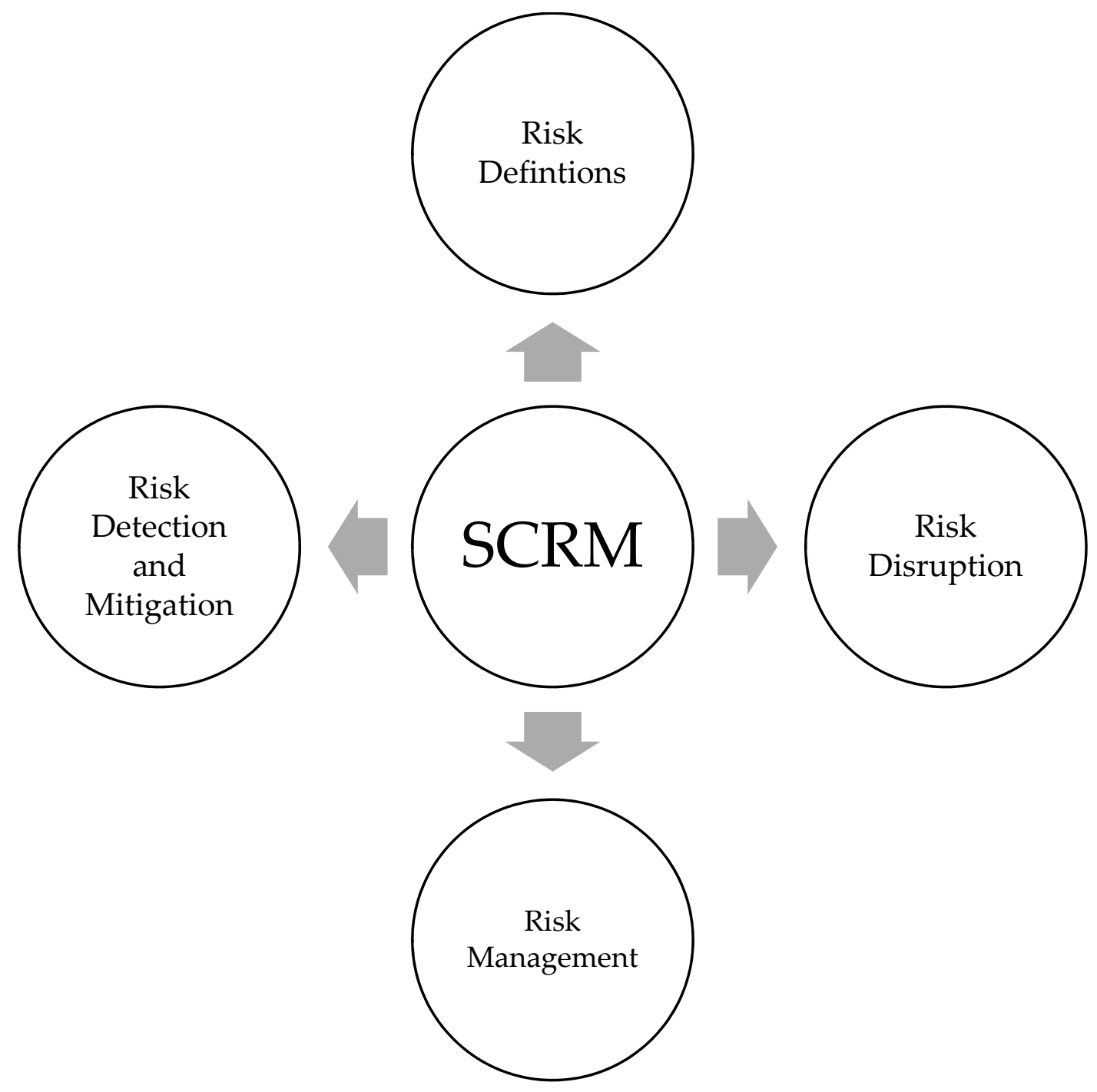

Figure 1. Supply chain risk management (SCRM) categories.

\subsection{SCRM Definitions}

The definitions of "supply chain risk" and SCRM are evolving (Diehl and Spinler 2013; Sodhi et al. 2012). A universally acceptable definition helps to identify, measure the chances of risk and its effect on the supply chains. This helps in adopting the most effective SCRM strategies. Therefore, standard definitions are vital (Diehl and Spinler 2013; Sodhi et al. 2012). Table 1 summarizes a few definitions of risk and SCRM.

Table 2 summarizes the findings and contributions of past literature reviews on SCRM. The authors have used various forms of literature review analysis, and each paper is unique in itself, which leaves the gap for further literature research in the field of SCRM. 
Table 1. Definitions of Risk and SCRM.

\begin{tabular}{ll}
\hline Authors & Definitions \\
\hline $\begin{array}{l}\text { Bogataj and Bogataj } \\
(2007)\end{array}$ & "The potential variation of outcomes that influence the decrease [in] value added at any activity cell in a chain." \\
\hline $\begin{array}{l}\text { Wagner and Bode } \\
(2006)\end{array}$ & $\begin{array}{l}\text { "The negative deviation from the expected value of a certain performance measure, resulting in negative } \\
\text { consequences for the focal firm." }\end{array}$ \\
\hline $\begin{array}{l}\text { Norrman and } \\
\text { Jansson (2004) }\end{array}$ & $\begin{array}{l}\text { "To collaborate with partners in a supply chain apply risk management process tools to deal with risks and } \\
\text { uncertainties caused by, or impacting on, logistics related activities or resources." }\end{array}$ \\
\hline $\begin{array}{l}\text { Tang (2007) } \\
\text { "The management of supply chain risks through coordination or collaboration among the supply chain } \\
\text { püttner (2005), }\end{array}$ & $\begin{array}{l}\text { "The identification and management of risks for the supply chain, through a coordinated approach amongst } \\
\text { supply chain members, to reduce supply chain vulnerability as a whole." }\end{array}$ \\
\hline $\begin{array}{l}\text { Goh et al. (2007) } \\
\text { "The identification and management of risks within the supply network and externally through a } \\
\text { coordinated approach amongst supply chain members to reduce supply chain vulnerability as a whole." }\end{array}$ \\
$\begin{array}{l}\text { "Characterized by a cross-company orientation aiming at the identification and reduction [in] risks not only } \\
\text { at the company level, but rather focusing on the entire supply chain." }\end{array}$ \\
\hline $\begin{array}{l}\text { "Any risks for the information, material and product flows from original suppliers to the delivery of the final } \\
\text { product for the end user." }\end{array}$ \\
$\begin{array}{l}\text { "An individual's perception of that total potential loss associated with the disruption of supply chain of a } \\
\text { particular item from a particular supplier." }\end{array}$ \\
$\begin{array}{l}\text { "The probability of an incident associated with inbound supply from individual supplier failures or the } \\
\text { supply market, occurring, in which its outcomes result in the inability of the purchasing firm to meet } \\
\text { customer demand or cause threats to customer life and safety." }\end{array}$ \\
\hline
\end{tabular}

Table 2. Literature reviews on SCRM.

\begin{tabular}{lll}
\hline Authors & Research Methodology & Key Findings/Contributions \\
\hline Jüttner et al. (2010) & $\begin{array}{l}\text { Focus group discussions, } \\
\text { interviews, and statistical analyses. }\end{array}$ & Developed four basic conceptual constructs around risks \\
\hline Khan and Burnes (2007) & Literature review & There is a need for analytical models \\
\hline $\begin{array}{l}\text { Natarajarathinam et al. } \\
(2009)\end{array}$ & Literature review & $\begin{array}{l}\text { Management of disruptions for rapid recovery needs } \\
\text { improvements. }\end{array}$ \\
\hline Rao and Goldsby (2009) & Literature review & $\begin{array}{l}\text { Classification of risks into environmental, industry, and } \\
\text { organizational risks }\end{array}$ \\
\hline Tang and Musa (2011) & $\begin{array}{l}\text { Literature survey and } \\
\text { bibliographic analysis }\end{array}$ & $\begin{array}{l}\text { There is a need for quantitative modeling in SCRM } \\
\text { Vanany et al. (2009) }\end{array}$ \\
\hline Williams et al. (2008) & Literature review & $\begin{array}{l}\text { Entreprise Resource Planning (ERP) will become a vital tool in } \\
\text { SCRM. There is a need for collaborative strategies in SCM. }\end{array}$ \\
\hline
\end{tabular}

\subsection{Risk Disruption}

Disruptions in supply chains are evolving to be more comprehensive and recurrent in the business environment (Narasimhan and Talluri 2009). The scale and rate of risk events in supply network are increasing (Blackhurst et al. 2005). Disruptions determine the robustness of SCM in a company (Hendricks and Singhal 2003, 2009). Disruption events are described as when "the tornado hits, the bomb explodes, a supplier goes out of business or the union begins a wildcat strike" (Sheffi and Rice 2005). There are different types of risk identified by various academicians and practitioners from the field of SCM. The risk classified by various authors can be elaborated to include the scale and risk occurrence 
(Blackhurst et al. 2005; Norrman and Jansson 2004; Sheffi and Rice 2005). Some other parameters to classify risks in SCM are: (i) based on the sources of risk and mitigation strategies (Chopra and Sodhi 2004); (ii) as organizational risks, environmental risks, and network risks (Jüttner et al. 2010); (iii) demand and supply risks (Manuj and Mentzer 2008); (iv) industry and organizational risks (Rao and Goldsby 2009); and (v) network risks (Garvey et al. 2015).

An uncertain business environment causes supply chain risks. The uncertain business environment results from cyclical business behavior, fluctuation in demands, or a disaster (Tang 2007). Therefore, uncertainty may be seen as a risk that can disrupt supply chain performance. Some authors have categorized risks in supply chains under operational risk, network risk, and external risks (Handfield and McCormack 2008). Operational risks are due to a strategic re-engineering failure arising from within the system. For example, a ferry named Moby Prince collided with a ship named Agip-Abruzzo ship in the Mediterranean Sea on 10 April 1991, causing a loss of 140 lives and 25,000 tons of oil; a fire in the Haven oil-tanker caused the loss of six lives, and 50,000 tons of oil on April 11, 1991 (Cigolini and Rossi 2010). Network risks are derived from the supplier network layers based on the title, vendor strategies, and agreements between the supply chain network vendors. Thirdly, external risks result from an organization's external environment, which poses a significant threat to the existing business environment. According to Silva and Reddy (2011), 73\% of the U.S. organizations suffered more than USD 1 billion in sales in the previous five years due to volatile disruption in the business cycle, with the most recurrent disruption caused by unmanageable natural disasters. Such turmoil often immobilizes supply chains for an extended duration (Altay and Ramirez 2010).

\subsection{Risk Management}

"Risk management refers to strategies, methods, and supporting tools to identify and control risk to an acceptable level" (Alhawari et al. 2012). Additionally, risk management can also be referred to as a synchronized set of actions and approaches to direct an organization to minimize the risk for achieving the organizational goals. Managing risks allows the decision-maker to understand and assess the impact of risk in a supply chain network. Controlling complexity leads to higher cost efficiency and reduces risks. Early oil tankers had two interconnected storage compartments causing instability. This design made oil tankers susceptible to overturning. The design of oil tankers was modified to have more independent compartments to provide deep water stability, although it was expensive to build such ships (Chopra and Sodhi 2014).

Supply chains evolve based on the market's requirements or manufacturing plants in different product development stages (Hayes and Wheelwright 1979). Furthermore, to reduce the global supply network's risk caused by increased economic engagements between nations, regional supply chains can replace global supply chains. For example, the world's largest distiller (Diageo PLC, London, UK) is shifting its supplier and distribution strategy from a global supply chain towards a more regional supply chain network. They minimize risks by sourcing locally and increase market share and profits by focusing on local markets (Lucas 2013). A manufacturing company (Li \& Fung Limited., Hong Kong, China) ties up sub-contracts with various vendors spread mostly across southern Asia, which reduces the dependency on one supplier in times of crisis, focusing on improving efficiency and reducing the risks in supply chains. Such regional transitions were envisaged due to various risks in global supply chains (Gurtu et al. 2015, 2016). The estimation of risk can lead to better risk management, reduce the extent of damage, and improve supply chain resilience. Long term investment in a robust supply chain network in an organization will reduce operational costs and be flexible enough to the changing and competitive business environment. Contingency plans to disruptions make companies resilient and provide a competitive advantage (Sheffi 2005). 


\subsection{Risk Detection and Mitigation Strategies}

Risk detection plays a pivotal role before disruption occurs. Force majeure disruptions are challenging to manage but can be estimated through conscious risk assessment strategies (Kleindorfer and Saad 2009; Norrman and Jansson 2004; Sheffi 2001), identifying risk indicators (Rodd 2003), and applying the principles of Total Quality Management (TQM) in sharing information among SCM partners (Lee and Whang 2005). Corporations should have contingency plans in the case of the occurrence of a disruptive event. Performance failures of a supply chain can be monitored through audits in an organization (Giunipero and Eltantawy 2004). Toyota have applied these principles in their supply chains (Dyer and Nobeoka 2000) and minimized the disruptions due to product recalls (Bates et al. 2007).

Strategies to control risk may be divided into seven categories: prevention, rescheduling, conjecture, numerical and economic, vertical integration, risk-sharing, and technology and security (Jüttner et al. 2010; Miller 1992). The prevention strategy is used when risks are linked with each product or its terrestrial markets, or close engagement with suppliers/customers is not possible. Divestiture of resources, delay of entry, or contributing to less ambiguous markets is prevention (Miller 1992). Ensuring flexibility and delay in spending refers to rescheduling (Bucklin 1965). Market demand, customization of products or services, input costs, product life cycle, and product modularity affects rescheduling (Chiou et al. 2002). The conjecture is the opposite of rescheduling (Bucklin 1965), and decisions are influenced by projected demand. Supply chain resources are leveraged to maximize the competitive advantage in serving the customers (Perry 1991). Financial risks are addressed through numerical and economic approaches (Chichilnisky and Heal 1998). The numerical approach is for a large population, e.g., insurance. The occurrence of an event for many people at the same time requires an economic approach. A few risks incentivize vertical integration because vertical integration reduces the risks due to better supply and demand control. Opportunism and asset specificity, capacity constraints, and improved supplier-buyer power balance are such incentives (Achrol et al. 1983; Ellram and Siferd 1998; Williamson 1979). Contracts with flexibility for possible changes in the environment reduces risks. Designing flexible contracts acts as a control mechanism (Macneil 1978). Outsourcing or offshoring transfers risks in SCM. Technology to detect nuclear, chemical, or biological elements exists and reduces the risk of carrying such shipments.

Organizations such as Container Security Initiative, Customs Trade Partnership Against Terrorism (CTPAT), and Operation Safe Commerce (OSC) act as instruments for global supply chain security (Mortimer 2004). The detection of a likely disruption from an unforeseen event is vital to risk mitigation. Therefore, SCRM facilitates a reduction in uncertainties and disruption while improving operational performance.

"A literature review is a systematic, explicit, and reproducible design for identifying, evaluating and interpreting the existing body of recorded documents" (Fink 1998). Literature reviews consist of two purposes: firstly, they summarize the present research findings by classifying patterns, themes, and issues. Secondly, they help to identify the conceptual content of the field (Meredith 1993) and contribute to theory development (Harland et al. 2006).

Literature reviews are content and structural analyses of the existing literature in an area (Brewerton and Millward 2001). The following steps suggested by Seuring and Müller (2008) have been used for this review:

1. Material collection;

2. Descriptive analysis;

3. Category selection;

4. Material evaluation.

This paper reviews and analyzes the existing academic literature on SCRM and discusses the future discourse of SCRM. 


\section{Analysis and Discussions}

The total number of documents published in peer-reviewed journals in the English language that used "risk" in their titles, keywords, or abstracts in the EBSCO premium database between 2010 and 2019 was 455 . This number includes papers published in ABDC and non-ABDC journals (Table 3 ). The papers published in non-ABDC journals were 143 $(455 / 143=31.43 \%)$.

Table 3. Document type for ABDC and non-ABDC journals.

\begin{tabular}{|c|c|c|c|c|c|c|c|c|c|c|c|}
\hline Document Type & 2010 & 2011 & 2012 & 2013 & 2014 & 2015 & 2016 & 2017 & 2018 & 2019 & Total \\
\hline \multicolumn{12}{|c|}{ Non-ABDC Journals } \\
\hline Article & 6 & 11 & 12 & 8 & 17 & 15 & 15 & 11 & 22 & 22 & 139 \\
\hline Case Study & & & & 1 & & 1 & & & & & 2 \\
\hline Opinion & & & & & & & 1 & & & & 1 \\
\hline Interview & & & & & & & & & 1 & & 1 \\
\hline Non-ABDC Total & 6 & 11 & 12 & 9 & 17 & 16 & 16 & 11 & 23 & 22 & 143 \\
\hline \multicolumn{12}{|c|}{ ABDC Journals } \\
\hline Article & 14 & 14 & 26 & 21 & 36 & 26 & 32 & 35 & 45 & 52 & 303 \\
\hline Case Study & & 1 & 1 & 1 & 1 & 1 & 2 & 2 & & & 9 \\
\hline ABDC Total & 14 & 15 & 27 & 22 & 37 & 27 & 34 & 37 & 45 & 52 & 312 \\
\hline Overall Total & 20 & 26 & 39 & 31 & 54 & 43 & 50 & 48 & 68 & 74 & 455 \\
\hline
\end{tabular}

There were a total of 143 research papers published between 2010 and 2019 in nonABDC journals. The papers were in the form of articles, case studies, opinions, and interviews. There were 139 articles, followed by one case study, and the rest were opinions and interviews. Forty-four articles on SCRM were published in the last two years of the study period, which were the highest in any two years between 2010 and 2019 and accounted for more than $31 \%$ of the publications.

There were $312(312 / 455=68.57 \%)$ papers published in ABDC listed journals as an article or a case study (Table 3). The number of research publications showed several research papers published on SCRM and the importance of risk management in the competitive and unpredictable business environment.

There were 303 research articles published in ABDC journals with nine case studies on the supply chain risks. However, no literature reviews were published. As stated earlier, the number of publications on risk factors in supply chains increased between 2010 and 2019 due to uncertainty and risk exposure. Economic engagements between nations due to globalization have sparked the need for efficient SCRM strategies to minimize the risk uncertainties.

Moreover, the papers were further analyzed into different ABDC ranking journal publications. Appendix A illustrates a detailed classification of journals listed in the ABDC category. There were $48 \mathrm{~A}^{*}$ category article publications between 2010 and 2019, compared to $200 \mathrm{~A}$ category research publications on SCRM. The remaining B and C category journals had 48 and 16 research publications, respectively. Therefore, research publications in the $\mathrm{A}$ category have received the highest number of publications. The analyses were classified into the number of papers published in top journals since 2010. Seven journals topped the list in the maximum publications related to risk management in the supply chain. The International Journal of Production Economics (IJPE) had the most publications in the studied period (Table 4).

The top journals can be further analyzed based on the publication of more than ten research papers. Table 5 illustrates the combination of the number of papers published in the number of journals. The International Journal of Production Economics published by Elsevier has 41, followed by the International Journal of Production Research with 31 publications. This is provided in Table 6 with the names of publishers. 
Table 4. Top journal publications.

\begin{tabular}{lc}
\hline \multicolumn{1}{c}{ Journal Name } & No. of Publications \\
\hline International Journal of Production Economics & 41 \\
International Journal of Production Research & 31 \\
Journal of Cleaner Production & 19 \\
Computers and Industrial Engineering & 19 \\
European Journal of Operational Research & 13 \\
Benchmarking: An International Journal & 11 \\
Industrial Management and Data Systems & 10 \\
\hline
\end{tabular}

Table 5. Information on the number of journals and papers published.

\begin{tabular}{ccc}
\hline Number of Papers Published & Number of Journals & Number of Papers in These Journals \\
\hline More than 10 & 6 & 134 \\
10 & 1 & 10 \\
9 & 1 & 9 \\
8 & 2 & 16 \\
7 & 1 & 7 \\
6 & 3 & 18 \\
5 & 3 & 15 \\
4 & 3 & 12 \\
3 & 11 & 33 \\
2 & 7 & 14 \\
1 & 44 & 44 \\
\hline Total & $\mathbf{8 2}$ & $\mathbf{3 1 2}$ \\
\hline
\end{tabular}

Table 6. Publishers of SCRM research papers in ABDC listed journals.

\begin{tabular}{lcc}
\hline \multicolumn{1}{c}{ Publisher } & No. of Articles & \% \\
\hline Elsevier B.V. & 130 & 41.67 \\
Emerald Publishing & 61 & 19.55 \\
Taylor \& Francis Ltd. & 53 & 16.99 \\
Wiley-Blackwell & 31 & 9.94 \\
Springer Nature & 9 & 2.88 \\
INFORMS: Institute for Operations Research & 5 & 1.60 \\
Aspen Publishers Inc. & 3 & 0.96 \\
Pennsylvania State University Press & 3 & 0.96 \\
IGI Global & 2 & 0.64 \\
American Society of Civil Engineers & 2 & 0.64 \\
Wageningen Academic Publishers & 2 & 0.64 \\
American Accounting Association & 1 & 0.32 \\
Adonis \& Abbey Publishers Ltd. & 1 & 0.32 \\
Palgrave Macmillan Ltd. & 1 & 0.32 \\
Food Distribution Research Society & 1 & 0.32 \\
Sloan Management Review & 1 & 0.32 \\
Global Academy of Training \& Research (GATR) Enterprise & 1 & 0.32 \\
IEEE & 1 & 0.32 \\
Kluwer Law International & 1 & 0.32 \\
Global Business Publications & 1 & 0.32 \\
Academic Press Inc. & 1 & 0.32 \\
Harvard University & 1 & 0.32 \\
\hline & 312 & $\mathbf{1 0 0}$ \\
\hline
\end{tabular}

\section{Research Implications in SCRM}

Global supply chains require a retrieval plan to ease the effects of disasters (Bryson et al. 2002). There needs to be a strategic plan, because uncertainties and risks surround the supply chain environment. Therefore, quick recovery is the prime objective after 
a risk incident has occurred. The formation of suitable risk recovery models also needs planning and a combination of information and human intervention. There are a few authors who have suggested empirically grounded research tools in SCM (Jüttner et al. 2010), such as mathematical programming models and simulation models (Rao and Goldsby 2009), analytical hierarchy processes (Vanany et al. 2009), complexity and graph theories (Colicchia et al. 2012), and the development of models considering interdisciplinary research (Khan and Burnes 2007) for further research in SCRM.

There are different payment processes in the imports and exports of goods. The two methods are prominent, namely, direct payment between the parties, and through a third party such as a bank. In the case of advance payment, the financial risk in a supply chain is high, particularly for making payments to new vendors in different countries. Direct payment requires trust and relationships and is avoided where trust between the two parties is not strong. In such cases, parties choose a financial mediatory, such as a bank, to make the payment through a letter of credit. Banks play a significant role, but this increases the cost of supply chains. The process involves considerable documentation, which delays the process and increases the risk due to currency fluctuations or trade embargoes.

Mingers and White (2010) suggest that a system can be projected for innovative ideas to the ambiguous business environment. A cohesive approach to SCRM needs to incorporate risk issues from industry practice (Tang and Musa 2011). Industry 4.0 is expected to significantly impact the visibility of the SC. Modern technologies such as Radio-frequency identification (RFID), ERP, and General Packet Radio Service (GPRS) will become important tools for SCRM (Rao and Goldsby 2009; Tang 2007; Vanany et al. 2009; Wilson 2007). However, almost all shipping transactions involve many documents such as seller contracts, charter party agreements, bills of lading, certificates of origin, port documents, letter of credit (LC), and many other documents related to a vessel's consignment (Gurtu and Johny 2019).

Identifying and harmonizing strategies for different types of risk is an essential factor for success in risk management (Chopra and Sodhi 2004). There needs to be a corrective approach for recurrent risks for evaluating the costs of increasing or decreasing inventories, capacity, flexibility, responsiveness, and capability. Managing disruptive risks will require designing supply chains where the resource in question (parts inventory or the number of suppliers) is never completely centralized (Chopra and Sodhi 2014). For instance, Samsung Electronics Co. Ltd. has two vendors to supply necessary electronic parts, even though the second vendor contributes only about $20 \%$ of the volume (Sodhi and Lee 2007). The implications of these principles are simple to understand. The benefit of having multiple fulfillment centers at various locations reduces the supply chain risk network without increasing the cost and minimizing the risk.

\section{Conclusions}

Supply chains form the backbone of the global economy and promote trade, consumption, and economic growth. The changing phases of globalization, lean manufacturing processes, and outsourcing to low-income countries have made supply chain networks more efficient and changed their supply chain risk profile. Due to globalization, intersupply chain competition has intensified; companies strive to deliver the best value to customers with greater efficiency at the lowest cost; communication with vendors/suppliers will play a vital role in many organizations (Mentzer et al. 2001; Wu et al. 2014). Supply chain cost reductions can be gained through optimally designed supply chain flows combined with goods' physical movement. This can be simplified by extending trade credit through conventional modes of distribution, reducing inventory levels, cost in supply chain management, and increase the access to trade finance organizations

This paper reviews the existing literature on SCRM and the exploration of risk factors in SCM. In this paper, we reviewed 455 international journal articles appearing between 2010 and 2019 in SCRM. We further refined all these articles according to publications in the ABDC ranking list (Appendix A), which was around 312 articles with the document type (Table 3) and top publishers (Table 6) in SCRM. Furthermore, the non-ABDC list 
of publications was considered to understand risk factors of SCM. The total number of papers published in the non-ABDC journals list was 143 (Table 3). This comprehensive classification of publications in top journals could help researchers conduct more detailed analyses based on risk factors affecting SCM networks. This indicates that the need for a greater focus on risks in global supply chains is needed. Risk assessments, risk analyses, and risk management are areas of interest in finance and insurance. However, the value of inventories in global supply chains and the impact of disruptions in global supply chains must be paid greater attention.

This study is not devoid of limitations. There are three main limitations of this paper. Firstly, the use of a single comprehensive, multidisciplinary database with a selection of only a few keywords; an article was likely unexplored if it did not contain the word "risk" in the title, keyword, or abstract. Secondly, we reviewed only international journal articles while excluding conference papers, master's and doctoral dissertations, textbooks, book chapters, unpublished articles, and notes. Thirdly, this study's goal was to present and categorize recent SCRM research and explore potential research gaps. Nevertheless, using this paper's categorization and summary results, further research can be conducted into specific underexplored or unexplored areas. This literature review is expected to benefit researchers to further explore studies in SCRM so that supply chain risks can be managed more effectively and efficiently.

Author Contributions: Both authors reviewed the articles and each other's work, making this review an almost-uniform combined production. All authors have read and agreed to the published version of the manuscript.

Funding: This research received no external funding.

Conflicts of Interest: The authors declare no conflict of interest.

\section{Appendix A}

Table A1. Research Articles Published in ABDC Journal by Category.

\begin{tabular}{|c|c|c|c|c|c|c|c|c|c|c|c|}
\hline Journal Title & 2010 & 2011 & 2012 & 2013 & 2014 & 2015 & 2016 & 2017 & 2018 & 2019 & Total \\
\hline \multicolumn{12}{|l|}{$A^{*}$} \\
\hline European Journal of Operational Research & 2 & 2 & & & 3 & 3 & 1 & & 1 & 1 & 13 \\
\hline Production E Operations Management & & 2 & & & 3 & & & & 1 & 2 & 8 \\
\hline Decision Sciences & 1 & & & & 1 & 2 & & & & 1 & 5 \\
\hline Journal of Operations Management & 1 & 1 & & 1 & & 2 & & & & & 5 \\
\hline Transportation Research: Part E & & & & & 1 & & & 1 & 1 & 1 & 4 \\
\hline Decision Support Systems & & & & & 2 & & & & & 1 & 3 \\
\hline Management Science & & & & & 1 & & 1 & & & 1 & 3 \\
\hline Human Resource Management & 1 & & & & & & & & & & 1 \\
\hline International Journal of Information Management & & & & & & & & & & 1 & 1 \\
\hline Journal of Construction Engineering \& Management & & & & & & 1 & & & & & 1 \\
\hline Journal of Management Information Systems & & & & 1 & & & & & & & 1 \\
\hline Management Accounting Research & & & & 1 & & & & & & & 1 \\
\hline Manufacturing E Service Operations Management & & & & & & & & & & 1 & 1 \\
\hline $\begin{array}{l}\text { Transportation Research Part A: Policy E Practice } \\
\text { A }\end{array}$ & & & & & & & & & 1 & & 1 \\
\hline International Journal of Production Economics & 1 & 2 & 8 & 2 & 5 & 5 & 9 & 6 & & 3 & 41 \\
\hline International Journal of Production Research & 1 & 3 & 2 & 2 & 2 & 6 & 5 & 2 & 3 & 5 & 31 \\
\hline Computers $\mathcal{E}$ Industrial Engineering & & & 1 & 1 & 1 & 1 & 1 & 6 & 2 & 6 & 19 \\
\hline Journal of Cleaner Production & & 1 & & 1 & & & 2 & 3 & 5 & 7 & 19 \\
\hline Industrial Management $\mathcal{E}$ Data Systems & & & 2 & & 1 & & 1 & & 6 & & 10 \\
\hline Omega & & 1 & & & & 3 & & 1 & 1 & 3 & 9 \\
\hline $\begin{array}{l}\text { International Journal of Operations \& Production } \\
\text { Management }\end{array}$ & & 1 & & & 1 & & & 1 & 4 & 1 & 8 \\
\hline Production Planning \& Control & 2 & & 2 & & & & & 1 & 2 & & 7 \\
\hline
\end{tabular}


Table A1. Cont.

\begin{tabular}{|c|c|c|c|c|c|c|c|c|c|c|c|}
\hline Journal Title & 2010 & 2011 & 2012 & 2013 & 2014 & 2015 & 2016 & 2017 & 2018 & 2019 & Total \\
\hline Annals of Operations Research & & & & 1 & & & 1 & 3 & & 1 & 6 \\
\hline International Journal of Logistics Management & & & 1 & & & 1 & 1 & 2 & 1 & & 6 \\
\hline $\begin{array}{l}\text { International Journal of Physical Distribution } \mathcal{E} \\
\text { Logistics Management }\end{array}$ & & 1 & & & & & 1 & 1 & 2 & 1 & 6 \\
\hline Computers E Operations Research & & & 1 & & & & & & 2 & 1 & 4 \\
\hline Journal of Business Logistics & 1 & & & 1 & & & & & 1 & 1 & 4 \\
\hline Journal of Purchasing $\mathcal{E}$ Supply Management & & & & & & & 2 & 1 & & & 3 \\
\hline Journal of Retailing $\mathcal{E}$ Consumer Services & & & & & & 1 & & & & 2 & 3 \\
\hline Journal of Supply Chain Management & & & 1 & & & & & & 1 & 1 & 3 \\
\hline Computers $\mathcal{E}$ Security & & & & & & & & 1 & & 1 & 2 \\
\hline Systems Research \& Behavioral Science & & & & & 2 & & & & & & 2 \\
\hline Applied Economics & & & & & & & & 1 & & & 1 \\
\hline Construction Management $\mathcal{E}$ Economics & 1 & & & & & & & & & & 1 \\
\hline Energy Policy & & & & & & & & & & 1 & 1 \\
\hline Harvard International Law Journal & & & & & 1 & & & & & & 1 \\
\hline IEEE Transactions on Engineering Management & & & & & & & 1 & & & & 1 \\
\hline IIE Transactions & & & 1 & & & & & & & & 1 \\
\hline International Journal of Project Management & & & & & & & 1 & & & & 1 \\
\hline $\begin{array}{l}\text { International Journal of Retail E Distribution } \\
\text { Management }\end{array}$ & & & & & & & & & 1 & & 1 \\
\hline Journal of Business $\mathcal{E}$ Industrial Marketing & & & & & & & & & 1 & & 1 \\
\hline Journal of Business Research & & & & & & & & & & 1 & 1 \\
\hline Journal of Enterprise Information Management & & & & & & & 1 & & & & 1 \\
\hline Journal of Global Information Management & & & & & 1 & & & & & & 1 \\
\hline Journal of Information Systems & & & 1 & & & & & & & & 1 \\
\hline Journal of Management in Engineering & & & & & & & & & & 1 & 1 \\
\hline MIT Sloan Management Review & & & & & 1 & & & & & & 1 \\
\hline Technovation & & & & & 1 & & & & & & 1 \\
\hline Transportation Science & & & & & & & & & & 1 & 1 \\
\hline B & & & & & & & & & & & \\
\hline Benchmarking: An International Journal & & 1 & 1 & 2 & 1 & & & 2 & 2 & 2 & 11 \\
\hline Journal of Manufacturing Technology Management & & & 1 & 1 & 1 & & 1 & & 1 & & 5 \\
\hline $\begin{array}{l}\text { International Journal of Logistics: Research } \mathcal{E} \\
\text { Applications }\end{array}$ & & & & 1 & & & 1 & & 1 & & 3 \\
\hline Management Decision & & & & & & & & 1 & 1 & 1 & 3 \\
\hline Thunderbird International Business Review & 1 & & & & & & & 2 & & & 3 \\
\hline $\begin{array}{l}\text { Transportation Journal (Pennsylvania State } \\
\text { University Press) }\end{array}$ & & & & 2 & & & 1 & & & & 3 \\
\hline Business Horizons & & & & & 2 & & & & & & 2 \\
\hline Business Process Management Journal & & & 1 & & & & & & & 1 & 2 \\
\hline $\begin{array}{l}\text { International Food \& Agribusiness Management } \\
\text { Review }\end{array}$ & & 1 & & & & & & & & 1 & 2 \\
\hline Journal of Marketing Channels & & & 1 & & & & 1 & & & & 2 \\
\hline Review of Quantitative Finance $\mathcal{E}$ Accounting & & & & & 1 & & & & 1 & & 2 \\
\hline Cogent Economics \& Finance & & & & & & 1 & & & & & 1 \\
\hline $\begin{array}{l}\text { International Journal of Computer Integrated } \\
\text { Manufacturing }\end{array}$ & & & 1 & & & & & & & & 1 \\
\hline $\begin{array}{l}\text { International Journal of Productivity \& Performance } \\
\text { Management }\end{array}$ & & & & & 1 & & & & & & 1 \\
\hline $\begin{array}{l}\text { International Journal of Quality \& Reliability } \\
\text { Management }\end{array}$ & & & & & & & 1 & & & & 1 \\
\hline Journal of Environmental Planning $\mathcal{E}$ Management & & & & 1 & & & & & & & 1 \\
\hline Journal of Intelligent Manufacturing & & & 1 & & & & & & & & 1 \\
\hline Journal of Manufacturing Systems & & & & 1 & & & & & & & 1 \\
\hline Journal of Revenue $\mathcal{E}$ Pricing Management & & & & & & & 1 & & & & 1 \\
\hline Multinational Finance Journal & 1 & & & & & & & & & & 1 \\
\hline Resources Policy & & & & & & & & 1 & & & 1 \\
\hline
\end{tabular}


Table A1. Cont.

\begin{tabular}{|c|c|c|c|c|c|c|c|c|c|c|c|}
\hline Journal Title & 2010 & 2011 & 2012 & 2013 & 2014 & 2015 & 2016 & 2017 & 2018 & 2019 & Total \\
\hline \multicolumn{12}{|l|}{ C } \\
\hline Intellectual Property E Technology Law Journal & & & & 1 & 2 & & & & & & 3 \\
\hline Journal of Risk Research & & & & 1 & 1 & 1 & & & & & 3 \\
\hline African Journal of Business \& Economic Research & & & & & 1 & & & & & & 1 \\
\hline Business Law Review & & & & & & & & 1 & & & 1 \\
\hline China Agricultural Economic Review & & & & & & & & & & 1 & 1 \\
\hline Competitiveness Review & 1 & & & & & & & & & & 1 \\
\hline Information Resources Management Journal & & & & & & & & & 1 & & 1 \\
\hline $\begin{array}{l}\text { International Journal of Managing Projects in } \\
\text { Business }\end{array}$ & & & & & & & & & 1 & & 1 \\
\hline Journal of Business E Economics Review (JBER) & & & & & & & & & 1 & & 1 \\
\hline Journal of Food Distribution Research & & & & & & & 1 & & & & 1 \\
\hline Journal of Management Development & & & 1 & & & & & & & & 1 \\
\hline Strategy E Leadership & & & & 1 & & & & & & & 1 \\
\hline Total & 14 & 16 & 27 & 22 & 37 & 27 & 35 & 37 & 45 & 52 & 312 \\
\hline
\end{tabular}

\section{References}

Achrol, Ravi Singh, Torger Reve, and Louis W. Stern. 1983. The Environment of Marketing Channel Dyads: A Framework for Comparative Analysis. Journal of Marketing 47: 55-67. [CrossRef]

Alhawari, Samer, Louay Karadsheh, Amine Nehari Talet, and Ebrahim Mansour. 2012. Knowledge-Based Risk Management framework for Information Technology project. International Journal of Information Management 32: 50-65. [CrossRef]

Altay, Nezih, and Andres Ramirez. 2010. Impact of Disasters on Firms in Different Sectors: Implications for Supply Chains. Journal of Supply Chain Management 46: 59-80. [CrossRef]

Aqlan, Faisal, and Sarah S. Lam. 2016. Supply chain optimization under risk and uncertainty: A case study for high-end server manufacturing. Computers \& Industrial Engineering 93: 78-87. [CrossRef]

Azad, Nader, Georgios K. D. Saharidis, Hamid Davoudpour, Hooman Malekly, and Seyed Alireza Yektamaram. 2012. Strategies for protecting supply chain networks against facility and transportation disruptions: An improved Benders decomposition approach. Annals of Operations Research 210: 125-63. [CrossRef]

Bates, Hilary, Matthias Holweg, Michael Lewis, and Nick Oliver. 2007. Motor vehicle recalls: Trends, patterns and emerging issues. Omega 35: 202-10. [CrossRef]

Blackhurst, Jennifer, Christopher W. Craighead, Debra Elkins, and Robert Beaudion Handfield. 2005. An empirically derived agenda of critical research issues for managing supply-chain disruptions. International Journal of Production Research 43: 4067-81. [CrossRef]

Bogataj, David, and Marija Bogataj. 2007. Measuring the supply chain risk and vulnerability in frequency space. International Journal of Production Economics 108: 291-301. [CrossRef]

Braithwaite, Alan, and Darren Hall. 1999. Risky business? Critical decisions in supply chain management. Supply Chain Practice 1: 40-55.

Brewerton, Paul, and Lynne Millward. 2001. Organizational Research Methods. Thousand Oaks: SAGE.

Bryson, Kweku-Muata, Harvey Millar, Anito Joseph, and Ayodele Mobolurin. 2002. Using formal MS/OR modeling to support disaster recovery planning. European Journal of Operational Research 141: 679-88. [CrossRef]

Bucklin, Louis P. 1965. Postponement, Speculation and the Structure of Distribution Channels. Journal of Marketing Research 2: 26-31. [CrossRef]

Cagliano, Anna Corinna, Alberto De Marco, Sabrina Grimaldi, and Carlo Rafele. 2012. An integrated approach to supply chain risk analysis. Journal of Risk Research 15: 817-40. [CrossRef]

Caniato, Federico, and James B. Rice, Jr. 2003. Building a secure and resilient supply network. Supply Chain Management Review 7: 22-30.

Chandra, Charu, and Janis Grabis. 2007. Supply Chain Configuration-Concepts, Solutions, and Applications, 1st ed. New York: Springer.

Chapman, Paul, Martin Christopher, Uta Jüttner, Helen Peck, and Richard Wilding. 2002. Identifying and Managing Supply Chain Vulnerability. Logistics \& Transport Focus 4: 59-64.

Chichilnisky, Graciela, and Geoffrey Heal. 1998. Managing Unknown Risks. The Journal of Portfolio Management 24: 85-91. [CrossRef]

Chiou, Jyh-Shen, Lei-Yu Wu, and Jason C. Hsu. 2002. The Adoption of Form Postponement Strategy in a Global Logistics System: The Case of Taiwanese Information Technology Industry. Journal of Business Logistics 23: 107-24. [CrossRef]

Choi, Kanghwa, Ram Narasimhan, and Soo Wook Kim. 2012. Postponement strategy for international transfer of products in a global supply chain: A system dynamics examination. Journal of Operations Management 30: 167-79. [CrossRef]

Chopra, Sunil, and ManMohan S. Sodhi. 2004. Managing risk to avoid supply-chain breakdown: By understanding the variety and interconnectedness of supply-chain risks, managers can tailor balanced, effective risk-reduction strategies for their companies. MIT Sloan Management Review 46: 53. 
Chopra, Sunil, and ManMohan S. Sodhi. 2014. Reducing the Risk of Supply Chain Disruptions. MIT Sloan Management Review 55: 73-80.

Christopher, Martin. 1992. Logistics: The Strategic Issues, 1st ed. New York: Chapman \& Hall.

Christopher, Martin, and Hau Lee. 2004. Mitigating supply chain risk through improved confidence. International Journal of Physical Distribution \& Logistics Management 34: 388-96. [CrossRef]

Christopher, Martin, and Helen Peck. 2004. Building the Resilient Supply Chain. The International Journal of Logistics Management 15: 1-14. [CrossRef]

Cigolini, Roberto, and Tommaso Rossi. 2010. Managing operational risks along the oil supply chain. Production Planning E Control 21: 452-67. [CrossRef]

Colicchia, Claudia, Richard Wilding, and Fernanda Strozzi. 2012. Supply chain risk management: A new methodology for a systematic literature review. Supply Chain Management: An International Journal 17: 403-18. [CrossRef]

Craighead, Christopher W., Jennifer Blackhurst, M. Johnny Rungtusanatham, and Robert B. Handfield. 2007. The Severity of Supply Chain Disruptions: Design Characteristics and Mitigation Capabilities. Decision Sciences 38: 131-56. [CrossRef]

de Matta, Renato. 2016. Contingency planning during the formation of a supply chain. Annals of Operations Research 257: 45-75. [CrossRef]

Dey, Asoke, Paul LaGuardia, and Mahesh Srinivasan. 2011. Building sustainability in logistics operations: A research agenda. Management Research Review 34: 1237-59. [CrossRef]

Diehl, Doreen, and Stefan Spinler. 2013. Defining a common ground for supply chain risk management-A case study in the fast-moving consumer goods industry. International Journal of Logistics Research and Applications 16: 311-27. [CrossRef]

Dyer, Jeffrey H., and Kentaro Nobeoka. 2000. Creating and managing a high-performance knowledge-sharing network: The Toyota case. Strategic Management Journal 21: 345-67. [CrossRef]

Ellis, Scott C., Raymond M. Henry, and Jeff Shockley. 2010. Buyer perceptions of supply disruption risk: A behavioral view and empirical assessment. Journal of Operations Management 28: 34-46. [CrossRef]

Ellram, Lisa M., and P. Sue Siferd. 1998. Total cost of ownership: A key concept in strategic cost management decisions. Journal of Business Logistics 19: 55.

Fernandes, Leão José, Ana Paula Barbosa-Póvoa, and Susana Relvas. 2011. Supply Chain Risk Management Review and a New Framework for Petroleum Supply Chains. In Quantitative Financial Risk Management. Edited by Dash Wu. Heidelberg: Springer, pp. 227-64.

Fink, Arlene. 1998. Conducting Research Literature Reviews: From Paper to the Internet. Thousand Oaks: Sage Publications.

Fugate, Brian, Funda Sahin, and John T. Mentzer. 2006. Supply Chain Management Coordination Mechanisms. Journal of Business Logistics 27: 129-61. [CrossRef]

Garvey, Myles D., Steven Carnovale, and Sengun Yeniyurt. 2015. An analytical framework for supply network risk propagation: A Bayesian network approach. European Journal of Operational Research 243: 618-27. [CrossRef]

Giunipero, Larry C., and Reham Aly Eltantawy. 2004. Securing the upstream supply chain: A risk management approach. International Journal of Physical Distribution \& Logistics Management 34: 698-713. [CrossRef]

Goh, Mark, Joseph Y. S. Lim, and Fanwen Meng. 2007. A stochastic model for risk management in global supply chain networks. European Journal of Operational Research 182: 164-73. [CrossRef]

Gurtu, Amulya, and Jestin Johny. 2019. Potential of blockchain technology in supply chain management: A literature review. International Journal of Physical Distribution E Logistics Management 49: 881-900. [CrossRef]

Gurtu, Amulya, Mohamad Y. Jaber, and Cory Searcy. 2015. Impact of fuel price and emissions on inventory policies. Applied Mathematical Modelling 39: 1202-16. [CrossRef]

Gurtu, Amulya, Cory Searcy, and M. Y. Jaber. 2016. Effects of offshore outsourcing on a nation. Sustainable Production and Consumption 7: 94-105. [CrossRef]

Hachicha, Wafik, and Manel Elmsalmi. 2014. An integrated approach based-structural modeling for risk prioritization in supply network management. Journal of Risk Research 17: 1301-24. [CrossRef]

Handfield, Robert B., and Kevin McCormack. 2008. Supply Chain Risk Management: Minimizing Disruptions in Global Sourcing. New York: Auerbach Publications.

Harland, C. M., R. C. Lamming, H. Walker, W. E. Phillips, N. D. Caldwell, T. E. Johnsen, L. A. Knight, and J. Zheng. 2006. Supply management: Is it a discipline? International Journal of Operations $\mathcal{E}$ Production Management 26: 730-53. [CrossRef]

Hayes, Robert H., and Steven C. Wheelwright. 1979. Link manufacturing process and product life cycles. Harvard Business Review 57: 133.

Hendricks, Kevin B., and Vinod R. Singhal. 2003. The effect of supply chain glitches on shareholder wealth. Journal of Operations Management 21: 501-22. [CrossRef]

Hendricks, Kevin B., and Vinod R. Singhal. 2009. An Empirical Analysis of the Effect of Supply Chain Disruptions on Long-Run Stock Price Performance and Equity Risk of the Firm. Production and Operations Management 14: 35-52. [CrossRef]

Huang, H. Y., Y. C. Chou, and S. Chang. 2009. A dynamic system model for proactive control of dynamic events in full-load states of manufacturing chains. International Journal of Production Research 47: 2485-506. [CrossRef]

Hubbard, Douglas W. 2007. How to Measure Anything: Finding the Value of "Intangibles" in Business. Hoboken: John Wiley \& Sons.

Hubbard, Douglas W. 2020. The Failure of Risk Management. Hoboken: Wiley. 
Jemison, David B. 1987. Risk and the Relationship Among Strategy, Organizational Processes, and Performance. Management Science 33: 1087-101. [CrossRef]

Jüttner, Uta. 2005. Supply chain risk management. The International Journal of Logistics Management 16: 120-41. [CrossRef]

Jüttner, Uta, Helen Peck, and Martin Christopher. 2010. Supply chain risk management: Outlining an agenda for future research. International Journal of Logistics Research and Applications 6: 197-210. [CrossRef]

Khan, Omera, and Bernard Burnes. 2007. Risk and supply chain management: Creating a research agenda. The International Journal of Logistics Management 18: 197-216. [CrossRef]

Kleindorfer, Paul R., and Germaine H. Saad. 2009. Managing Disruption Risks in Supply Chains. Production and Operations Management 14: 53-68. [CrossRef]

Knight, Frank H. 1921. Risk, Uncertainty and Profit. Boston and New York: Houghton Mifflin.

Kouvelis, Panos, and Jian Li. 2008. Flexible Backup Supply and the Management of Lead-Time Uncertainty. Production and Operations Management 17: 184-99. [CrossRef]

Lavastre, Olivier, Angappa Gunasekaran, and Alain Spalanzani. 2012. Supply chain risk management in French companies. Decision Support Systems 52: 828-38. [CrossRef]

Lee, Hau L., and Seungjin Whang. 2005. Higher supply chain security with lower cost: Lessons from total quality management. International Journal of Production Economics 96: 289-300. [CrossRef]

Lucas, Louise. 2013. Diageo overhauls its supply chain. Financial Times, March 11.

Macneil, Ian R. 1978. Contracts: Adjustment of Long-Term Economic Relations under Classical and Neoclassical, and Relational Contract Law. Northwestern University Law Review 72: 854-905.

Manuj, Ila, and John T. Mentzer. 2008. Global supply chain risk management strategies. International Journal of Physical Distribution $\mathcal{E}$ Logistics Management 38: 192-223. [CrossRef]

MeInyk, Steven A., Gary L. Ragatz, and George A. Zsidisin. 2005. The dark side of supply chain management. Supply Chain Management Review 9: 46-52.

Mentzer, John T., James S. Keebler, Nancy W. Nix, Carlo D. Smith, and Zach G. Zacharia. 2001. Defining Supply Chain Management. Journal of Business Logistics 22: 1-25. [CrossRef]

Meredith, Jack. 1993. Theory Building through Conceptual Methods. International Journal of Operations E Production Management 13: 3-11. [CrossRef]

Miller, Kent D. 1992. A Framework for Integrated Risk Management in International Business. Journal of International Business Studies 23: 311-31. [CrossRef]

Mingers, John, and Leroy White. 2010. A review of the recent contribution of systems thinking to operational research and management science. European Journal of Operational Research 207: 1147-61. [CrossRef]

Mortimer, L. Downey. 2004. The Challenge of Transportation Security. Supply Chain Management Review 8: 9.

Narasimhan, Ram, and Srinivas Talluri. 2009. Perspectives on risk management in supply chains. Journal of Operations Management 27: 114-18. [CrossRef]

Natarajarathinam, Malini, R. Glenn Richey, Ismail Capar, and Arunachalam Narayanan. 2009. Managing supply chains in times of crisis: A review of literature and insights. International Journal of Physical Distribution E Logistics Management 39: 535-73. [CrossRef]

Norrman, Andreas, and Ulf Jansson. 2004. Ericsson's proactive supply chain risk management approach after a serious sub-supplier accident. International Journal of Physical Distribution $\mathcal{E}$ Logistics Management 34: 434-56. [CrossRef]

Perry, James H. 1991. Emerging Economic and Technological Futures: Implications for Design and Management of Logistics Systems in the 1990s. Journal of Business Logistics 12: 1.

Prasad, Sameer, Rimi Zakaria, and Nezih Altay. 2016. Big data in humanitarian supply chain networks: A resource dependence perspective. Annals of Operations Research 270: 383-413. [CrossRef]

Rao, Shashank, and Thomas J. Goldsby. 2009. Supply chain risks: A review and typology. The International Journal of Logistics Management 20: 97-123. [CrossRef]

Ritchie, Bob, and Clare Brindley. 2007. Supply chain risk management and performance. International Journal of Operations E Production Management 27: 303-22. [CrossRef]

Rodd, Zolkos. 2003. Many companies still ignoring supply-chain risks. Business Insurance 37: 21.

Roloff, Julia, and Michael S. Aßländer. 2010. Corporate Autonomy and Buyer-Supplier Relationships: The Case of Unsafe Mattel Toys. Journal of Business Ethics 97: 517-34. [CrossRef]

Seuring, Stefan, and Martin Müller. 2008. From a literature review to a conceptual framework for sustainable supply chain management. Journal of Cleaner Production 16: 1699-710. [CrossRef]

Sheffi, Yossi. 2001. Supply Chain Management under the Threat of International Terrorism. The International Journal of Logistics Management 12: 1-11. [CrossRef]

Sheffi, Yossi. 2005. Resilient Enterprise Overcoming Vulnerability for Competitive Advantage. Cambridge: The MIT Press.

Sheffi, Yossi, and James B. Rice, Jr. 2005. A Supply Chain View of the Resilient Enterprise. MIT Sloan Management Review 47: 41.

Silva, Juliano, and Surender Reddy. 2011. A framework for reducing disaster risks in supply chains. International Journal of Business Research 11: 112-17.

Slack, Nigel, and Michael Lewis. 2002. Operations Strategy, 3rd ed. Harlow: Prentice-Hall. 
Sodhi, ManMohan S., and S. Lee. 2007. An analysis of sources of risk in the consumer electronics industry. J Oper Res Soc 58: 1430-39. [CrossRef] [PubMed]

Sodhi, ManMohan S., Byung-Gak Son, and Christopher S. Tang. 2012. Researchers' Perspectives on Supply Chain Risk Management. Production and Operations Management 21: 1-13. [CrossRef]

Sofyalıoğlu, Çiğdem, and Burak Kartal. 2012. The Selection of Global Supply Chain Risk Management Strategies by Using Fuzzy Analytical Hierarchy Process-A Case from Turkey. Procedia—Social and Behavioral Sciences 58: 1448-57. [CrossRef]

Spekman, Robert E., and Edward W. Davis. 2004. Risky business: Expanding the discussion on risk and the extended enterprise. International Journal of Physical Distribution \& Logistics Management 34: 414-33. [CrossRef]

Tang, Christopher S. 2007. Robust strategies for mitigating supply chain disruptions. International Journal of Logistics Research and Applications 9: 33-45. [CrossRef]

Tang, Ou, and S. Nurmaya Musa. 2011. Identifying risk issues and research advancements in supply chain risk management. International Journal of Production Economics 133: 25-34. [CrossRef]

Teigen, Karl Halvor. 1996. Risk-taking behavior, J. Frank Yates (ed.), Chichester: John Wiley, 1992, 345 pp., ISBN 0-471-92250-1, (hc), ISBN 0-471-95140-4 (pb). Journal of Behavioral Decision Making 9: 73-74. [CrossRef]

Thun, Jörn-Henrik, Martin Drüke, and Daniel Hoenig. 2011. Managing uncertainty-An empirical analysis of supply chain risk management in small and medium-sized enterprises. International Journal of Production Research 49: 5511-25. [CrossRef]

Vahid Nooraie, S., and Mahour Mellat Parast. 2016. Mitigating supply chain disruptions through the assessment of trade-offs among risks, costs and investments in capabilities. International Journal of Production Economics 171: 8-21. [CrossRef]

Vanany, Iwan, Suhaiza Zailani, and Nyoman Pujawan. 2009. Supply Chain Risk Management: Literature Review and Future Research. International Journal of Information Systems and Supply Chain Management 2: 16-33. [CrossRef]

Verbano, Chiara, and Karen Venturini. 2011. Development paths of risk management: Approaches, methods and fields of application. Journal of Risk Research 14: 519-50. [CrossRef]

Véronneau, Simon, and Jacques Roy. 2014. Security at the source: Securing today's critical supply chain networks. Journal of Transportation Security 7: 359-71. [CrossRef]

Vorst, Jack G. A. J., Andrie J. M. Beulens, W. Wit, and Paul Beek. 1998. Supply Chain Management in Food Chains: Improving Performance by Reducing Uncertainty. International Transactions in Operational Research 5: 487-99. [CrossRef]

Wagner, Stephan M., and Christoph Bode. 2006. An empirical investigation into supply chain vulnerability. Journal of Purchasing and Supply Management 12: 301-12. [CrossRef]

Wang, Xihui, Yunfei Wu, Liang Liang, and Zhimin Huang. 2014. Service outsourcing and disaster response methods in a relief supply chain. Annals of Operations Research 240: 471-87. [CrossRef]

Williams, Zachary, Matthew Waller, Jason E. Lueg, and Stephen A. LeMay. 2008. Supply chain security: An overview and research agenda. The International Journal of Logistics Management 19: 254-81. [CrossRef]

Williamson, Oliver E. 1979. Transaction-Cost Economics: The Governance of Contractual Relations. The Journal of Law and Economics 22: 233-61. [CrossRef]

Wilson, Martha C. 2007. The impact of transportation disruptions on supply chain performance. Transportation Research Part E: Logistics and Transportation Review 43: 295-320. [CrossRef]

$\mathrm{Wu}$, Ing-Long, Cheng-Hung Chuang, and Chien-Hua Hsu. 2014. Information sharing and collaborative behaviors in enabling supply chain performance: A social exchange perspective. International Journal of Production Economics 148: 122-32. [CrossRef]

Xanthopoulos, Anastasios, Dimitrios Vlachos, and Eleftherios Iakovou. 2012. Optimal newsvendor policies for dual-sourcing supply chains: A disruption risk management framework. Computers $\mathcal{E}$ Operations Research 39: 350-57. [CrossRef]

$\mathrm{Xu}$, Jie, Jun Zhuang, and Zigeng Liu. 2015. Modeling and mitigating the effects of supply chain disruption in a defender-attacker game. Annals of Operations Research 236: 255-70. [CrossRef]

Zsidisin, George A. 2003. A grounded definition of supply risk. Journal of Purchasing and Supply Management 9: 217-24. [CrossRef] 